tympanoplasty: prognostic factors, Artículo Original, 2340- 3438.

4. Gans H. Tympanoplasty in children. Arch Otolaryngol. 1963;77:350.

5. Pyman C. Signposts to successful tympanoplasty, With special reference to children. J Otolaryngol Soc Aust. 1964;1:233-47.

6. Lau $\mathbf{T}$, Tos $\mathbf{M}$. Tympanoplasty in children. An analysis of late results. Am J Otol. 1986;7(1):55-9.
7. Cao Minh Thành (2012). Phẫu thuât nôi soi vá nhĩ: kết quả và kinh nghiệm thực tiến, Tạp chí Y học Viêt nam; tâp 393; tháng 5 số 1; trang 76-79.

8. Anita Jeyakumar, Sean Miller, Ron B. Mitchell (2014) Bailey's head and neck surgeryotolaryngology, Adenotonsillar Disease in Children, chapter 95, pp. 1430

9. Phưng Thị Vân Anh (2012), "Đánh giá kết quả tạo hình màng nhĩ đướng ống tai", Luận văn tốt nghiệp thạc sỹ, trường Đại học Y Hà Nội.

\title{
NGHIÊN CỨU ĐĂC ĐIỂM ĐAU TRONG BÊNNH ZONA THEO CÁC THANG ĐIỂM ĐAU XUẤT XỨ THẦN KINH
}

\section{TÓM TẮT}

Cơ sở: Bệnh zona là một trong những bệnh da thường gặp, do virus Herpes Zoster gây nên. Đau trong zona là triệu chứng chức năng chính đưa bệnh nhân đến cơ sở y tế, đăc biêt là chuyên khoa Thần Kinh. Đau là biểu hiện đặc thù ở cả ba giai đoạn của bênh với tính chất đau thân kinh nổi bât. Rất khó lượng giá cảm giác đau nhưng một số thang điểm đau có thể dùng đê đánh giá mức độ và tính chất đau xuất xứ thần kinh như thang điểm LANSS và DN4. Mục tiêu: Áp dụng một số thang điểm đau quốc tế đánh giá mức độ và tính chất đau xuất xứ thần kinh trong bệnh zona. Phương pháp: Chúng tôi tiến hành nghiên cứu theo phương pháp mô tả cắt ngang, tiến cứu trên 73 bệnh nhân được chẩn đoán bệnh zona. Sử dung thang điểm đau LANSSS và DN4 để đánh giá mức độ và tính chất đau. Kết quả: $70 \%$ đến $90 \%$ bệnh nhân được đánh giá đau theo thang điểm đau xuất xứ thần kinh (LANSS). 60,3\% bệnh nhân có tính chất đau xuất xứ thần kinh điển hình (điểm LANSS từ 21 trở lên). $20 \%$ đến $80 \%$ bệnh nhân có tính chất đau đánh giá theo thang điểm đảau xuất xứ thân kinh bộ 4 câu hỏi (DN4). 95,9\% bệnh nhân có tính chất đau xuất xứ thần kinh điển hình (điểm DN4 từ 4 trở lên). Tính chất đau xuất xứ thần kinh và mức độ đau sau zona có mối tương quan chăt chẽ với tuổi bệnh nhân. Kết luận: Đau zona có các tính chất điển hình của đau xuất xứ thần kinh. Tuổi càng cao, càng có nguy cơ đau sau zona và các triệu chứng đau đánh giá theo điểm LANSS và bộ 4 cẩu hỏi (DN4) càng đây đủ.

Tư khóa: LANSS, DN4, đau xuất xứ thân kinh, bệnh zona.

\section{SUMMARY \\ STUDY ON CHARACTERISTIC FEATURES OF}

*Bệnh viện Da liễu trung ương

**Bệnh viênn Bãi Cháy Quảng ninh

***Bênh viên Bach Mai.

Chịu trách nhiệm chính: Phạm Thị Thu Hương

Email: drthuhuong01@gmail.com

Ngày nhận bài: 2.8.2021

Ngày phản biên khoa hoc: 29.9.2021

Ngày duyệt bài: 5.10 .2021

\section{NEUROPATHIC PAIN IN ZONA}

Background: Shingles is one of the common skin conditions, caused by the Herpes Zoster virus. Pain in shingles is a major functional symptom that brings patients to medical specialties, especially neurology. Pain is characteristic of all three stages of zona with prominent neuropathic pain. However, pain is difficult to evaluate. There are a number of international pain scales that can be used to assess the level and nature of neuropathic pain, such as the LANSS and DN4 scores. Objective: To apply some international pain scales to assess the level and nature of neuropathic pain in shingles. Methods: We conducted a crosssectional descriptive study of 73 patients diagnosed with shingles. We used LANSS and DN4 pain scales to assess the level and nature of neuropathic pain. Results: $70 \%$ to $90 \%$ of the patients suffering from pain were evaluated on the basis of neurological pain score (LANSS) $60.3 \%$ of patients had typical neuropathic pain (LANSS score of 21 or higher). $20 \%$ to $80 \%$ of patients were evaluated according to the Neuropathic pain set of 4 questions (DN4). $95.9 \%$ of patients had typical neuropathic pain (DN4 score of 4 or higher). Neuropathic pain and postoperative pain were significantly correlated with the age of patients. Conclusion: Shingles pain had typical properties of neuropathic pain. The higher the risk, the greater the risk of post-shingles and pain symptoms assessed after LANSS and the set DN4 questions.

Key words: LANSS, DN4, neuropathic pain, shingles.

\section{I. ĐẶT VẤN ĐỀ}

Bệnh zona là một trong những bệnh da thường gặp, do virus Herpes Zoster. Đau có thể biểu hiện cả ba giai đoạn của bệnh. Đau sau zona là tình trạng đau kéo dài trên một tháng sau khi nhiễm Herpes zoster (khi vùng da tổn thương đã lành hoàn toàn). Đau được giải thích theo cơ chế: tăng hoạt tính màng và phóng điện lạc vị, tăng mẫn cảm ngoại vi và mất kiểm soát ức chế.

Đau là triệu chứng cơ năng chính đưa bệnh nhân đến cơ sở y tế, đặc biệt là chuyên khoa Thần kinh và Da liễu. Đau trong giai đoạn tiên 
triệu có thể chẩn đoán nhầm là nhức đầu, viêm mống mắt (thể mắt), đau do bệnh tim, đau thần kinh tọa... Đau trong giai đoan toàn phát và giai đoạn sau zona thường rất khó điều trị, đau dai dẳng, kéo dài từ một đến nhiêuu tháng, nhiều năm thậm chí lâu hơn nữa, gây ra lo âu, trầm cảm ảnh hưởng đến chất lượng cuộc sống của bệnh nhân.

Đau là một trải nghiệm hoàn toàn cá nhân, rất khó lượng giá. Hiện nay đã có rất nhiều đề tài trong trong $Y$ văn nghiên cứu về đă̆c điểm lâm sàng và các yếu tố liên quan đến đau, tuy nhiên còn ít đề tài áp dụng các thang điểm đau xuất xứ thần kinh để đánh giá các tính chất đau trong bệnh zona. Vì vậy chúng tôi tiến hành nghiên cứu đề tài với mục tiêu áp dụng một số thang điểm đau quốc tế đánh giá mức độ đau, tính chất đau xuất xứ thần kinh trong bệnh zona.

\section{II. ĐỐI TƯỢNG VÀ PHƯƠNG PHÁP NGHIÊN CỨU}

1. Đối tượng nghiên cứu: 73 bệnh nhân được chẩn đoán mắc bệnh zona ở các giai đoạn.

- Tiêu chuẩn chọn bệnh nhân

+ Bệnh nhân có đau khu trú ở một vùng

+ Có biểu hiện bệnh zona ở các giai đoạn liên quan đến vùng đau

- Tiêu chuẩn chẩn đoán bệnh Zona chủ yếu dựa vào các biểu hiện lâm sàng ở từng giai đoạn

- Các trường hợp không điển hình sẽ được hội chẩn với chuyên khoa Da liễu để làm các xét nghiệm chuyên khoa sâu.

- Tiêu chuẩn loại trừ bệnh nhân

+ Đau zona kèm theo một bênh khác (thoát vị đĩa đệm, vết thương, phẫu thuật...)

+ Bệnh Zona không gây đau (tê hoặc mất cảm giác do bệnh khác).

+ Bệnh nhẩn sa sút trí tuệ, có bệnh tâm thần.

+ Bệnh nhân có viêm da tiếp xúc.

2. Phương pháp nghiên cứu:

- Chúng tôi tiến hành nghiên cứu theo phương pháp mô tả cắt ngang, tiến cứu.

- Các biến số nghiên cứu: các tính chất đau xuất xứ thần kinh và các điểm đau xuất xứ thần kinh theo thang điểm LANSS và DN4, mối tương quan giữa tuổi với điểm đau xuất xứ thần kinh.

\section{KẾT QUẢ NGHIÊN CỨU}

3.1. Đặc điểm chung của đối tượng nghiên cứu

Bảng 3.1. Phân bố bệnh nhân theo giới, tuổi \begin{tabular}{|c|c|c|c|}
\hline Nhóm tuối & Nam & Nữ & Tống \\
\hline
\end{tabular}

\begin{tabular}{|c|c|c|c|c|}
\hline$\leq 30$ & 4 & 2 & 6 & 8,2 \\
\hline $31-40$ & 2 & 3 & 5 & 6,8 \\
\hline $41-50$ & 5 & 3 & 8 & 11 \\
\hline
\end{tabular}

\begin{tabular}{|c|c|c|c|c|}
\hline $51-60$ & 12 & 9 & 21 & 28,8 \\
\hline $61-70$ & 5 & 10 & 15 & 20,5 \\
\hline$>70$ & 4 & 14 & 18 & 24,7 \\
\hline Tống & $\mathbf{3 2}$ & $\mathbf{4 1}$ & $\mathbf{7 3}$ & $\mathbf{1 0 0}$ \\
\hline
\end{tabular}

Nhân xét: Tỷ lê mắc bênh của hai nhóm nam và nữ gần tương đương nhau. Bệnh nhân trên 50 tuổi chiếm khoảng $70 \%$. Nhóm tuổi dưới 50 có tỷ lệ thấp hơn. Tuổi trung bình là 58,21 $\pm 16,57$.

3.2 Áp dụng thang đau xuất xứ thân kinh (LANSS)

Bảng 3.2. Các tính chất đau trong zona đánh giá theo thang đau xuất xứ thần kinh (LANSS)

\begin{tabular}{|c|c|c|}
\hline Triệu chứng đau & $\begin{array}{c}\text { Số bệnh } \\
\text { nhẩn }\end{array}$ & $\begin{array}{c}\text { Tỷ lệ \% } \\
\text { (n= 73) }\end{array}$ \\
\hline Cảm giác kim châm, kiến bò & 72 & 98,6 \\
\hline Đau kèm biến đổi màu sắc da & 59 & 80,8 \\
\hline $\begin{array}{c}\text { Đau làm thay đối cảm nhận } \\
\text { của da khi sờ vào }\end{array}$ & 61 & 83,6 \\
\hline $\begin{array}{c}\text { Đau đột ngột (tính chất } \\
\text { như dao đâm, điê̂n giật, } \\
\text { bỏng buốt) }\end{array}$ & 65 & 89,0 \\
\hline Đau rát kiểu bỏng buốt & 57 & 78,1 \\
\hline Loạn cảm đau & 53 & 72,6 \\
\hline Tăng cảm giác đau & 59 & 80,8 \\
\hline
\end{tabular}

Nhân xét: Đa số bênh nhân đều có đầy đủ các tính chất đau đánh giá theo thang điểm đau xuất xứ thần kinh (LANSS), với tỳ lệ tương đương nhau từ $70 \%$ đến trên $90 \%$. Như vậy tính chất đau xuất xứ thần kinh đánh giá theo LANSS rất điển hình.

Bảng 3.3. Điểm đau xuất xứ thần kinh theo (LANSS)

\begin{tabular}{|c|c|c|}
\hline $\begin{array}{c}\text { Điểm đau xuất xứ } \\
\text { thẩn kinh (LANSS) }\end{array}$ & $\begin{array}{c}\text { Số bê̂nh } \\
\text { nhẩn }\end{array}$ & $\begin{array}{c}\text { Tỷ lệ } \\
\text { \%o }\end{array}$ \\
\hline Dưới 12 điếm & 14 & 19,1 \\
\hline $12-15$ & 7 & 9,6 \\
\hline $16-20$ & 8 & 11,0 \\
\hline $21-24$ & 44 & 60,3 \\
\hline Tống & $\mathbf{7 3}$ & $\mathbf{1 0 0}$ \\
\hline
\end{tabular}

Nhân xét: Trên $80 \%$ bênh nhân có điếm đau xuất xứ thần kinh (LANSS) từ 12 trở lên. Trên $60 \%$ có tính chất điển hình (điểm từ 21 trở lên).

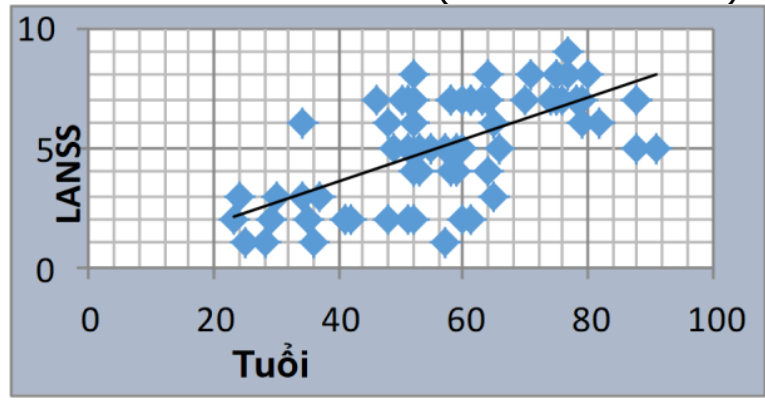

Biểu đồ 3.1. Môi tương quan giữa tuổi với 
điểm đau xuất xứ thần kinh (LANSS)

Nhận xét: Có mối tương quan đồng biến khá chă̆t chẽ giữa tuổi và điểm đau xuất xứ thần kinh (LANSS) $(r=0,523, p<0.001)$.

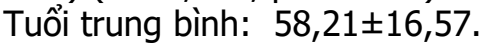

Phương trình tuyến tính:

Điểm đau xuất xứ thần kinh (LANSS) = 0,273*Tuổi + 0,263.

3.3. Áp dụng Thang đau xuất xứ thân kinh bộ 4 câu hỏi (DN4)

Bảng 3.4. Các tính chất đau đánh giá theo thang điểm đau xuất xứ thần kinh bộ 4 câu hói (DN4)

\begin{tabular}{|c|c|c|}
\hline Triệu chứng đau & $\begin{array}{c}\text { Số bệnh } \\
\text { nhẩn }\end{array}$ & $\begin{array}{c}\text { Tỷ lệ \%o } \\
\text { (n=73) }\end{array}$ \\
\hline Bỏng buốt & 65 & 89,0 \\
\hline Tê cóng & 28 & 38,4 \\
\hline Như điện giật & 65 & 89,0 \\
\hline Kiến bò & 72 & 98,5 \\
\hline Châm chích & 72 & 98,5 \\
\hline Tê bì & 60 & 82,2 \\
\hline Ngứa & 50 & 68,5 \\
\hline Giảm cảm giác sờ & 37 & 50,7 \\
\hline Giảm cảm giác đau & 16 & 21,9 \\
\hline Kích thích nhè gây đau & 59 & 80,8 \\
\hline tái phát hoặc đau nặng lên & 59 \\
\hline
\end{tabular}

Nhận xét: Trên $80 \%$ bệnh nhân có tính chất đau như điện giật, châm chích, kiến bò, tê bì, bỏng buốt. Các tính chất đau khác chiếm ít hơn khoảng từ $20 \%$ đến gần $70 \%$. Chứng tỏ các tính chất đau xuất xứ thần kinh rất điển hình.

Bảng 3.5. Điểm đau xuât xứ thần kinh theo bộ 4 câu hỏi (DN4)

\begin{tabular}{|c|c|c|}
\hline $\begin{array}{c}\text { Điếm bố 4 câu } \\
\text { hởi (DóN4) }\end{array}$ & $\begin{array}{c}\text { Số bê̂nh } \\
\text { nhẩn }\end{array}$ & Tỷ lệ \% \\
\hline Dưới 4 & 3 & 4,1 \\
\hline 4 đến dưới 6 & 22 & 30,1 \\
\hline $6-8$ & 37 & 50,7 \\
\hline Trên 8 & 11 & 15,1 \\
\hline Tống & $\mathbf{7 3}$ & $\mathbf{1 0 0}$ \\
\hline
\end{tabular}

Nhận xét: Trên $90 \%$ bệnh nhân có điểm bộ 4 câu hỏi (DN4) từ 4 trở lên, như vậy phần lớn các trường hợp có tính chất đau xuất xứ thần kinh.

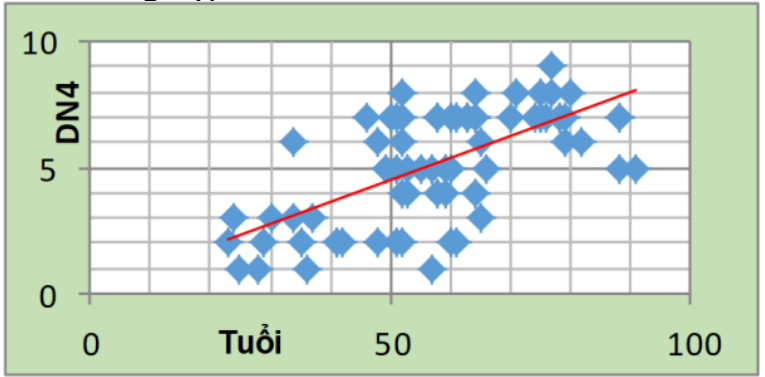

Biểu đồ 3.2. Mối tương quan giữa tuổi với điểm bộ 4 câu hỏi (DN4)

Nhận xét: Có mối tương quan đồng biến khá chặt chẽ giữa nhóm tuổi và điểm bộ 4 câu hỏi (DN4) $(r=0,576, p<0,001)$.

Tuổi trung bình: 58,21 $\pm 16,57$.

Phương trình tuyến tính:

Điểm bộ 4 câu hỏi $(D N 4)=0,332 *$ Tuổi + 0,323.

\section{BÀN LUẬN}

Nghiên cứu 73 bệnh nhân, chúng tôi thây tỷ lệ gặp ở bệnh nhân nam và nữ tương đương nhau, trong đó nam chiếm $43,8 \%$ và nữ chiếm $56,2 \%$. Nhiều nghiên cứu trên thế giới cũng cho thấy tỷ lệ mắc bệnh giữa nam và nữ gần như xấp xỉ nhau, hoặc nếu có sự khác biệt cũng không có ý nghĩa thống kê. Như vậy không có sự khác biệt về tỷ lệ mắc bệnh giữa hai giới nam và nữ. Bệnh nhân trong nghiên cứu này có độ tuổi từ 23 đên 91 , tuổi trung bình là 58,21 \pm 33.14 . Bệnh nhân ở nhóm trên 50 tuổi chiếm tỷ lệ 75,3\%, cao hơn nhóm dưới 50 tuổi, sự khác biệt có ý nghĩa thống kê (với $p<0,05)$.

Đau xuất xứ thần kinh (neuropathic pain) là chứng đau do những thương tổn nguyên phát hoặc những rối loạn chức năng trong hệ thần kinh gây nên. Đau trong bệnh zona là đau xuất xứ thần kinh ngoại vi (peripheral neuropathic pain) [1].

Cơn đau thường là triệu chứng chủ yếu trong tất cả các giai đoạn của bệnh zona, với tỷ lệ đến 90\% bệnh nhân. Cường độ của cơn đau được đánh giá theo chủ quan của cả bệnh nhân và thâyy thuốc nên rất khó lượng giá [2].

Để đánh giá tính chất đau trong bệnh zona, chúng tôi sử dụng Thang điểm đánh giá triệu chứng và dấu hiệu đau xuất xứ thần kinh (LANSS: The Leeds Assessment of Neuropathic Symtoms and Signs) và Thang điểm bộ 4 câu hỏi về đau xuất xứ thần kinh (DN4: Douleur neuropathique en 4 questions) để phát hiện triệu chứng đau xuất xứ thần kinh với các đau thực thể khác.

Thang điểm LANSS được đánh giá dựa trên phân tích mô tả năm triệu chứng cảm giác và hai triệu chứng qua thăm khám cảm giác. Bảng 3.2 cho thấy các triệu chứng theo thang điểm LANSS xuất hiện ở hâuu hết các bệnh nhân và chiếm tỷ lệ cao từ $70 \%$ đến trên $90 \%$. Bảng 3.3 cho thấy các bệnh nhân chủ yếu có điểm trên hoặc bằng 12 theo thang điểm LANSS: có 59 bệnh nhân $(80,9 \%)$, trong đó điểm từ 21 đến 24 là chủ yếu 
có 44 bệnh nhân (60,3\%). Điều đó chứng tỏ các bệnh nhân đau trong zona là đau do tổn thương dây thần kinh ngoại vi.

Thang điểm DN4 được đánh giá dựa vào hai câu hỏi về đau có bẩy mục và hai trắc nghiệm về da có ba mục. Các bảng 3.5 cho thây các bệnh nhân chủ yếu có điểm trên hoặc bằng 4 với DN4, gồm 70 bệnh nhân (95,6\%), trong đó điểm từ 6 đến 8 có 37 bệnh nhân, $(50,7 \%)$. Cũng như kết quả thang điểm LANSS, các bệnh nhân đau trong zona là đau xuất xứ thần kinh.

Các tính chất đau trong bệnh zona đánh giá theo thang điểm LANSS gồm: cảm giác kim châm, kiến bò $(98,6 \%)$, đau đột ngột như bị (dao đâm, điện giật, bỏng buốt) có 65 bệnh nhân $(89 \%)$, đau làm thay đổi cảm nhận của da khi sờ vào $(83,6 \%)$, tăng cảm giác đau $(80,8 \%)$, loạn cảm đau $(72,6 \%)$, đau rát như bị bỏng $(72,6 \%)$, và đau kèm biến đổi màu sắc da ( 80,8\%). Còn đánh giá theo bộ bốn câu hỏi DN4 (bảng 3.4) cho thấy: đau như bỏng buốt $(89,0 \%)$, tê cóng $(38,4 \%)$, như bị điện giật $(89,0 \%)$, kiến bò $(98,6 \%)$, châm chích $(98,6)$, tê bì $(82,2 \%)$, ngứa $(68,5)$, giảm cảm giác sờ $(50,7 \%)$, giảm cảm giác đau $(21,9 \%)$ và kích thích nhẹ đau tái diễn hoặc đau nặng lên $(80,8 \%)$. Kết quả này cũng tương tự như nghiên cứu của các tác giả khác [3]. Các tác giả này giải thích triêu chứng di cảm là do hoat đông bất thường của các thụ thể hướng tâm đã bị tổn thương do virus varicella-zoter, gây phóng điện lạc vị. Tổn thương làm tăng hoạt tính của kênh natri, thay đổi cân bằng giữa hai kênh gây suy giảm dẫn truyền gồm mất cảm giác, giảm cảm giác, giảm cảm giác đau (triệu chứng âm tính) và tăng kích thích gồm đau tự phát: dị cảm, loạn cảm, đau do kích thích, tăng cảm giác đau, loạn cảm đau (triệu chứng dương tính) [3]. Các sợi cảm giác tổn thương mọc chồi từ sợi trục me có nhiều kênh natri hơn bình thường nên có tính kích thích rất cao và dễ xảy ra phóng điện lạc vị và hậu quả gây dị cảm, loạn cảm, gây kim châm, bỏng rát, bỏng buốt [4],[5].

Các bất thường về cám giác và đau cùng tồn tại một cách nghịch lý, mỗi bệnh nhân có nhiều triệu chứng kết hợp và có thể thay đổi theo thời gian trong ngày dù chỉ do một cơ chế bệnh sinh. Đau ở các giai đoạn có thể liên tục hoặc không liên tục với các triệu chứng khác nhau, như kim châm, kiến bò hoặc đột ngột như dao đâm, cảm giác ngứa, ngứa ran hoặc tê bì,... [5]. Nhiều bệnh nhân có loạn cảm (đau tạo ra từ một kích thích bình thường không gây đau) như tiếp xúc của quần áo hay tắm rửa hoặc gió thổi nhẹ vào da [5] và triệu chứng này ảnh hưởng rõ rệt đến sinh hoạt hang ngày của bệnh nhân ví dụ không dám tắm vì sợ đau, đặc biệt trong giai đoạn toàn phát. Điều đó minh chứng rõ hơn tính chất đau thần kinh ngoại vi trong bệnh zona và triệu chứng loạn cảm đau có thể giúp dự đoán nguy cơ cao phát triển đau sau zona [5].

Xét mối tương quan điểm đau đánh giá theo thang điểm đau xuất xứ thần kinh (LANSS) ( biểu đồ 3.2) và Bộ 4 câu hỏi (DN4) (biểu đồ 3.3), chúng tôi thấy có sự tương quan đồng biến khá chặt chẽ với tuổi của bệnh nhân $(r=0,523$, $p<0,001)$ và $(r=0,567, p<0,001)$. Như vậy tuổi càng cao, càng có nguy cơ bị đau sau zona và các triệu chứng đau đánh giá theo thang điểm LANSS và Bộ 4 câu hỏi DN4 càng đầy đủ. Vấn đề này cũng được ghi nhận theo $Y$ văn trong nước và trên thế giới; một nghiên cứu ở Hoa Kỳ cho kêt quả hai phần ba trường hợp bị mắc zona ở những người từ 50 tuổi trở lên, và đau sau zona là $30 \%$ [6].

\section{KẾT LUẬN}

Đau trong bệnh zona là một triệu chứng đặc thù và là một trong những biến chứng thường gặp của bệnh. Đau trong bệnh zona có tính chất điển hình của đau xuất xứ thần kinh. Mức độ đau sau zona có mối tương quan khá chặt chẽ với tuổi bệnh nhân: tuổi càng cao càng có nguy cơ đau sau zona. Có thể sử dụng thang điểm đau xuất xứ thần kinh LANSS và Bộ 4 câu hỏi DN4 để lượng giá mức độ đau trong bệnh zona.

\section{TÀI LIỆ THAM KHẢO}

1. Nguyễn Văn Chương (2006), "Các hội chứng rối loạn cảm giác", Thực hành lầm sàng thần kinh hoc Tầp 2, NXB Y hoc, 196-204

2. Johnson R. W., Wasner G., Saddier P., Baron R. (2008). Herpes zoster and postherpetic neuralgia: optimizing management in the elderly patient. Drugs Aging, 25:991-1006.

3. Woolf C. J. (2004). Life Sci.; $75: 2605-2610$

4. Oaklander A. L, Bowsher D., Galer B., Haanpää M., Jensen M. P. (2003): Herpes zoster itch: preliminary epidemiologic data. J Pain, 4:338-343.

5. Yawn B. P, Gilden D. (2013). The global epidemiology of herpes zoster. Neurology; 81:928-30.

6. Dworkin R. H, Gnann J. W. et al (2008). Diagnosis and assessment of pain associated with herpes zoster and postherpetic neuralgia. J Pain, 9(Suppl 1):S37-S44. 